Leslie W. Ross

\title{
Some Aspects of Soviet Education
}

S subsequent Russian space adventures which followed that momentous event, American interest in Soviet education has been reflected in the public utterances of a number of journalists, educators, statesmen, scientists, politicians, reporters, and scholars. Several of our national leaders in these professions base their comments on trips made to the Soviet Union within the last two or three years. They have uniformly come away tremendously impressed with the educational activities they have observed there.

It is significant that Soviet interest in American education is nearly equal to our interest in theirs. President Hatcher of the University of Michigan, upon his return from a recent trip to Russia, said of the Soviets:

The country whose dedication to education has been their inspiration is the United States of America."

The progressive ideas of the followers of John Dewey apparently were rather widely practiced in Russia in the twenties and early thirties. $^{2}$

We in America for the last two decades have witnessed a considerable focusing of emphasis on the general education movement. Although this movement has been variously defined, it is usually agreed that general education consists of that knowledge which "all men should have." In this paper I shall try to examine, among other things, the degree to which Soviet education is providing those concepts which are referred to

\footnotetext{
1 Harlan Hatcher, "Our Soviet Neighbors," Speech delivered at the University of Michigan, Ann Arbor, May 21, 1959.

${ }^{2}$ George S. Counts, The Challenge of Soviet Education (New York: McGraw-Hill, 1957) p. 60-68.
}

as general education in this country. The reader should bear in mind that Russian education is historically patterned more nearly after continental European models than after American, and that in the European scheme general education as we know it is centered almost entirely in the preuniversity experience of the student.

\section{The Soviet Educational Structure}

In looking at the structure of Soviet education, we must first recognize that a program of school reform, to be implemented over a five-year period and designed to lay more emphasis on practical training, was initiated in the fall of 1959. In terms of structure, the major effect of the reform legislation (enacted on December 24, 1958) will be to add one year to the seven- and ten-year schools described below. At the present time, because of the recency of the new policy, we can only describe the system which has most recently obtained, and use this as a basis for evaluating the projected changes as they develop. Early reports indicate that full realization of these changes will take some time. Further discussion of the reform legislation appears later in this paper under "Current Reform."

Education in the USSR is centered around a ten-year elementary-secondary program which is organized on a 4-3-3 basis. There are schools of three types: four-, seven-, and ten-year schools. There is a standard program of studies for all students in the entire Soviet Union (with a few minor concessions in terms of regional languages and literature), so that every student is studying the same subjects in every grade of the ten-year

Mr. Ross is a graduate fellow in higher education at the University of Michigan, Ann Arbor. 
system. This is true regardless of whether the school is a four-, seven-, or ten-year school; there is complete compatibility between schools for any grade-level and for any region of the Soviet Union.

The Soviets maintain that they have achieved universal, compulsory, seven-year education, and in recent years they appeared confident of raising this to the ten-year level by 1960 . Interpretation of the new schoolreform program for 1959-1963 indicates, however, that the latter goal has been abandoned in favor of compulsory eight-year education, with secondary schooling to be completed on a voluntary basis. ${ }^{3}$ Certain curricular changes will also be made in the elementary and secondary schools.

Students who complete the ten-year curriculum are eligible to take the university matriculation examinations (except certain high-honors students who are excused). Students who complete the ten-year or seven-year curriculum may go into a tekhnikum, from which the outstanding students may after four years apply for admission to an engineering institute.

There are various other kinds of schoolslabor reserve schools and agricultural schools -which will not be discussed here since they are essentially vocational in nature.

The higher-education system consists of $\mathbf{3 3}$ universities, plus 732 specialized highereducational institutions, variously known as institutes, academies, higher schools, and conservatories. There are also an undetermined number of military, security police, and Communist party schools.4

In the Soviet Union, the general education of youth takes on forms which are much different from those in the United States. It should be constantly remembered, in any study of Soviet education, that there is a totality of effect of the various curricular and extra-curricular influences on the stu-

${ }^{3}$ William K. Medlin, "Appendix B-Soviet Educational Reorganizations for 1959-1963," in United States Department of Health, Education, and Welfare; Office of Education, Soviet Commitment to Education (Washington, D.C.: Govermment Printing Office, 1959) p. 132.

- United States Department of Health, Education, and Welfare; Office of Education, Education in the USSR (Washington, D.C.: Government Printing Office, 1958) p. 185. dent which is not easily perceived from a separate examination of each of these influences.

Thus, all the aspects of Soviet education which are discussed in this paper may be considered to be facets of the system of general education. The goal is to mold the ideal Soviet citizen, and considerable effort is expended by the state to do this systematically and efficiently.

\section{Objectives of Soviet Education}

Much can be learned and much can be understood about Soviet education in the process of a careful examination of its objectives. Just as we in the United States have certain hoped-for learnings which we believe all pupils should attain, so the Soviets have developed purposes for general education.

The difference between American and Soviet purposes centers on three factors. First, in the Soviet Union there is a quite different concept of the knowledge essential to every human being and the kind of individual the educational system is trying to produce; secondly, there is a marked difference in the degree of individual freedom permitted in the choice of subject matter; and thirdly, there is a vast difference in the ideology which underlies each structure.

The place of the individual and the knowledge that he should have are viewed entirely in terms of state needs in the Soviet Union. The state is all that counts in Soviet life, and education is considered the prime agency for accomplishing the state's goals in the planned Soviet economy. The following citation reveals the determination behind this concept:

The purpose of Soviet education is "the training of educated, thoroughly developed, active builders of a communist society."

The reaction of one American observer to this objective is as follows:

It is not the individual around whom the educational system is built, but the state, which, by identifying itself with pursuits of the common good, attempts the ruthless subordination

" "How Russia Does It," (London) Times Educational Supplement, November 29, 1957. p. 1520. 
of the individual-his rights, tastes, choices, privileges, and his training-to its own needs. ${ }^{\circ}$

It is difficult for Americans to understand the total grip which the Soviet state has on the individual, and it is this basic problem that accounts for much of our misunderstanding of this system. In education all details of the educational system are predicated on this cornerstone of Soviet life. All observers, unless they have some reason for bias, have recognized and admitted the primacy of this facet of Soviet education. When this influence is fully appreciated, other observations of the educational system take on a different cast.

A second distinguishing feature of the Soviet system is the determinism of the state in setting forth the curriculum which the student must follow. There is little or no individual freedom of choice of subject matter. The Russian rulers believe that any kind of waste motion or inefficient activity is, in effect, an act of treason against the state. Thus the state has determined in great detail what its needs will be in various occupations and it looks to the educational system to produce the requisite individuals in the proper numbers and with the proper training.

While this concept is quite incomprehensible in the United States, it is, nevertheless, one of the dominating features of Russian education, and from it, obviously, stem a whole chain of effects on institutions and students. The impressive Soviet successes in science and technology can be almost entirely attributed to this planning of the kind and degree of training which students will receive. The effect of this kind of thinking on the curriculum will be examined later.

Two more observations should be made at this point. First, the Russians are not only training scientists and technologists for their own needs, but they are admittedly raining them for export to aid underdeveloped countries and, of course, to eventually draw such countries into the Soviet bloc. The machine aspects of the system are thus all the more apparent, since there

' Nicholas DeWitt (National Science Foundation), Soriet Professional Manpower (Washington, D.C.: Government Printing Office, 1955) p. 1 . is an avowed belief in the economic superiority of Russian communism.

We must also realize that an important objective of the Soviet educational scheme is to provide for women essentially the same opportunities which are available to men. The U.S. Office of Education reports that women constitute about 80 per cent of education students, 60 per cent of medical students, and 30 to 40 per cent of technical and engineering students, in semi-professional and higher education programs. 7 Women engage actively in almost every phase of Soviet life, including barbering, road repairing, and various heavy trades. Again the orientation is from the viewpoint of the needs of the statea worker is a worker regardless of whether male or female. The Russians feel compelled to bend every possible effort toward tangible achievement in the area of industrial and agricultural production.

There are, finally, tremendous ideological differences between the United States and the Soviet Union. Russia is ruled by the Communist party according to principles of Marxist materialism. The influence of ideology on the Soviet youth will be examined later in some detail under the heading of "Indoctrination." Something of its scope can be grasped from this statement which ap. peared in the (London) Times Educational Supplement:

The whole process of Soviet education from kindergarten to university is based on Marxist materialism and dominated by the conception of producing a young Communist-submissive, disciplined, and unquestioning. ${ }^{8}$

\section{The Curriculum}

The goals of any educational system can only be achieved through the curriculum and the dominant interests of the groups which control education will be reflected in the kinds of curricula which they produce for their schools.

In the Soviet Union there is no exception to this rule. We have already seen how the needs of the state are the all-important fac-

\footnotetext{
${ }^{7}$ United States Department of Health, Education, and Welfare, Education in the USSR, op. cit. p. 16.

8 "Soviet Educational Structure," (London) Times Educational Supplement, November 20, 1953. p. 981.
} 
tor in determining educational policy. The influence extends directly to the school curricula.

The reform legislation recently enacted is a reflection of state concern over the curricular content of the Soviet schools. There has been a growing awareness on the part of the state of a central shortcoming in the ten-year schools: they have been training too many youngsters in the academic pre-university line and too few in the vocational and industrially oriented lines of education. 9 The intent now is to insert into the curriculum more direct emphasis on vocational training and the educational advantages of physical labor, and to extend the seven- and ten-year schools by one year to accommodate these changes. Since the details of the anticipated curriculum changes are as yet unclear, we can only judge what the new school is going to be in terms of what we know has been the case of the tenyear school.

The uniformity of curricula in the tenyear elementary-secondary education of all Soviet youth has two main bases: (1) it

Medlin, op. cit. p. 127. facilitates the movement of families with children, thus increasing worker mobility, and (2) it expedites state control over the entire educational machine.

We might add that it also makes it easier for outsiders to study and evaluate their educational system, and this point applies particularly to the context of this paper. In trying to determine what knowledge is deemed important enough to be imparted to all youth of a country, we can make some interesting observations on those things that the country honors most.

In Russia, we find that mathematics, the sciences, and languages have a major place in the curriculum. Table I depicts the universal ten-year curriculum of the Soviet schools.

Six significant features of the ten-year curriculum have been succinctly summarized by Counts:

In the first place, all children follow the same curriculum from the first grade to the tenth, except for differentiation between the sexes in the realm of military-physical preparation and opportunity to choose among foreign languages, if two or more are offered in the same school. In the second place, all ten-year schools

TABle I

Curriculum for Soviet Elementary and Secondary Schools •

\begin{tabular}{|c|c|c|c|c|c|c|c|c|c|c|c|c|}
\hline \multirow[b]{2}{*}{ Subject } & \multicolumn{10}{|c|}{ Number of Class Hours Per Week } & \multicolumn{2}{|c|}{ Total Hours } \\
\hline & 1 & 2 & 3 & 4 & 5 & 6 & 7 & 8 & 9 & 10 & Week & Year \\
\hline Russian Language and Literature . . . . & 13 & 13 & 13 & 9 & 9 & 8 & 6 & 5 & 4 & 4 & 84 & 2,772 \\
\hline Mathematics . . . . . . . . . . . & 6 & 6 & 6 & 6 & 6 & 6 & 6 & 6 & 6 & 6 & 60 & 1,980 \\
\hline History . . . . . . . . . . . . . . & & & & 2 & 2 & 2 & 2 & 4 & 4 & 4 & 20 & 660 \\
\hline Constitution of USSR $\ldots \ldots \ldots \ldots \ldots$ & & & & & & & & & & 1 & 1 & 33 \\
\hline Geography . . . . . . . . . . . . & & & & 2 & 3 & 2 & 2 & 2 & 3 & & 14 & 462 \\
\hline Biology . . . . . . . . . . . . . . & & & & 2 & 2 & 2 & 3 & 2 & 1 & & 12 & 396 \\
\hline Physics . . . . . . . . . . . . . & & & & & & 2 & 3 & 3 & 4 & 4 & 16 & 528 \\
\hline Astronomy . . . . . . . . . . . . & & & & & & & & & & 1 & 1 & 33 \\
\hline Chemistry . . . . . . . . . . . & & & & & & & 2 & 2 & 3 & 4 & 11 & 363 \\
\hline Psychology . . . . . . . . . . . . . & & & & & & & & & & 1 & 1 & 33 \\
\hline Foreign Language $\ldots \ldots \ldots \ldots \ldots \ldots$ & & & & & 4 & 4 & 3 & 3 & 3 & 3 & 20 & 660 \\
\hline Physical Culture. . . . . . . . . . . & 2 & 2 & 2 & 2 & 2 & 2 & 2 & 2 & 2 & 2 & 20 & 660 \\
\hline Drawing . . . . . . . . . . . . & 1 & 1 & 1 & 1 & 1 & 1 & & & & & 6 & 198 \\
\hline Drafting $\ldots \ldots \ldots \ldots \ldots \ldots$ & & & & & & & 1 & 1 & 1 & 1 & 4 & 132 \\
\hline Singing $\ldots \ldots \ldots \ldots \ldots \ldots$ & 1 & 1 & 1 & 1 & 1 & & & & & & 6 & 198 \\
\hline Labor . . . . . . . . . . . . . . . . . & 1 & 1 & 1 & 1 & 2 & 2 & 2 & & & & 10 & 330 \\
\hline $\begin{array}{l}\text { Practical Work (Agricultural Economy, } \\
\text { Machine Operation, and Electro- }\end{array}$ & & & & & & & & & & & & \\
\hline Techniques) $\ldots \ldots \ldots \ldots \ldots \ldots$ & & & & & & & & 3 & 2 & 2 & 7 & 231 \\
\hline Excursions $\ldots \ldots \ldots \ldots \ldots \ldots \ldots$ & & & & & & & & & & & & 293 \\
\hline Total $\ldots \ldots \ldots \ldots \ldots \ldots \ldots \ldots$ & 24 & 24 & 24 & 26 & 32 & 32 & 32 & 33 & 33 & 33 & 293 & 9,962 \\
\hline
\end{tabular}

- From George S. Counts, The Challenge of Soviet Education (New York: McGraw-Hill, 1957) p. 77. 
throughout the Soviet Union teach the same subjects in the same grades, except the nonRussian schools in which the Russian language is taught as an additional subject from the third to the tenth grade inclusive. In the third place, the school year is long, ranging from 213 days in the first three grades to 230 in the tenth, and the school week embraces six days. In the fourth place, the curriculum emphasizes the native language, mathematics, and physical science. Morevover, according to the plan, the Soviet pupil is carried much further in mathematics and science than the American pupil. Though not stated in the table (Table I), mathematics includes trigonometry, as well as astronomy. And the study of physics and chemistry begins in the sixth and seventh grades respectively. Both science and mathematics are classified as "important subjects." In the fifth place, the study of foreign languages, usually English, German, and French, is taken very seriously. Instruction begins in the fifth grade. In the sixth place, systematic physical education is provided in all grades from the first to the tenth for the purpose of "cultivating such qualities in the younger generation as bravery, persistence and will." The reader should not forget those gold and silver medals shining and beckoning in the distance which open freely the doors to the higher schools. ${ }^{10}$

The concept of "polytechnic" education looms large in Soviet thought. The word recurs again and again in pedagogical writings, and takes on a certain aura of sanctity. It is considered very unwise to slander or otherwise try to retard polytechnic education.

There has been a long-standing policy that an essential part of every individual's education, boys and girls alike, is some firsthand training and experience in the manual arts. There must be a certain love for and devotion to manual labor in the breast of every Soviet citizen. This can best be achieved through the inclusion of a required block of labor and practical work in the universal ten-year curriculum. In addition, several kinds of institutions exist which are almost exclusively devoted to vocational or semiprofessional education.

One of the most noteworthy differences between United States and Soviet education lies in the treatment of the liberal arts in

${ }^{10}$ Counts, op. cit. p. 76-77. higher education curricula. Time magazine reports:

Quality aside, the big trouble with Soviet education is that in overemphasizing specialization, it is turning out a generation almost wholly ignorant of the sort of liberal arts education known in the West. ${ }^{11}$

In the Soviet Union the institutions of higher education, including the universities, have primarily a utilitarian and vocational orientation. Except for those students majoring in the social sciences or the humanities, there is little or no content in these areas provided for or required of the typical university student. At the University of Moscow, the faculties of philosophy, philology, economics, history, law, and journalism are still quartered in the old university buildings opposite the Kremlin. They lie six miles distant from the magnificent new University plant on Lenin Hills, where the sciences are housed. The program of each university student is almost completely taken up with courses in his specialty.

\section{Indoctrination}

Indoctrination in Communist ideology is an integral part of the general education of every Soviet student. This is freely admitted by the Communist officials and is quite obvious from an examination of some of the course materials. The Dodges reported that students seemed to be the most thoroughly indoctrinated group they met. ${ }^{12}$ The intensity of this propaganda campaign is often underestimated by Americans. Lenin is quoted as follows:

Everything that contributes to the building of a Communist society is moral; everything that hinders this is immoral and amoral. ${ }^{13}$

The student cannot escape the party-line indoctrination. Not only are the schools a vehicle for propaganda dissemination, but a whole host of publicity techniques are employed which are educational in effect. There is even a specific agency for this purpose:

11 "The One-Track Mind," Time 66:46; November 28,1955 .

${ }^{12}$ Homer and Norton Dodge, "Russia Gains Over U.S. in Educating Scientists," U.S. News and World Report 39:97; September 16, 1955.

${ }^{13}$ Counts, op. cit. p. 112. 
Agitprop, the party apparatus dealing with agitation and propaganda, is "keeper of the sacred flame." It does not create the party line, but disseminates it, and is responsible for what one astute and knowledgeable observer, former Senator William Benton, calls the "most stupendous psychological manipulation in history." It maintains more than 6,000 schools, and has 375,000 full-time propagandists and agitators in the field. Each is armed with "scripture"-an 824-page book, called Guide for the Propagandist and Agitator. ${ }^{14}$

Mr. Benton also stated, after his 1955 visit to the Soviet Union, that "in Russia [the American] discovers that the rulers seek to convert the total culture into a giant propaganda apparatus." 15

The evidences of the effects of the propaganda techniques on students are marked. Misinformation as to American accomplishments and intentions are particularly noticeable. Some observers have indicated that there has been a campaign to transfer much of the hatred for the Nazis to a similar intense hatred of Americans. ${ }^{16}$ Even the phrasing of the questions asked American visitors reflects the Communist party's influence. These questions have a classic wifebeating quality, and are apt to go something like this: "When are you Americans going to stop your aggressive, warlike actions against our beloved country?" Thayer has observed:

While the American government and private institutions have been training thousands of specialists on the Soviet Union, the Soviet Government has so far as I know not trained a single serious student in American affairs. ${ }^{17}$

John Gunther says:

14 John Gunther, Inside Russia Today (London: Hamish Hamilton, 1958) p. 229.

15 William Benton, "William Benton Reports on the Voice of the Kremlin," The 1956 Encyclopedia Brittanica Book of the Year (Chicago: P. F. Collier, 1956). Feature article, pages unnumbered.

${ }^{16}$ Merle Fainsod, How Russia is Ruled (Cambridge: Harvard University Press, 1958) p. 260

${ }^{17}$ Charles W. Thayer, "I Found Russia Changed," Saturday Evening Post 228:158; April 14, 1956.
The Russians have the most formidable educational machine in the world, but they are also the most ignorant people in the world about affairs outside their own country. ${ }^{18}$

While indoctrination and education are theoretically quite distinct, the Communists have taken great pains to see that the textbooks used in the ten-year curricula reflect the proper party line. Most notorious has been the repeated re-writing of history texts to "correct" (or remove altogether) impressions given concerning the prowess of particular Russian leaders, or the role of the Soviet Union in history, or the successes of the Communist party on the world scene.

There is a feeling now that while the activities of the propagandists can have great and insidious effects in the presentation of social science materials, it is difficult, if not impossible, to insert doctrinaire materials into the study of mathematics or engineering or the physical sciences. The fact that it is these very subjects that the Soviets are now concentrating upon most heavily leads some observers to believe that the influence of party indoctrination must not be so pronounced as it has been in the past.

Even in areas such as history and political science, the effect of repeated changes in the party line has been detrimental to the effort to indoctrinate the youth of the country. The United States Office of Education ${ }^{19}$ reports that many teachers have postponed or neglected as long as possible a thorough teaching of subjects where party shifts may occur, because they realize that by waiting until the eleventh hour, i.e., just before students are scheduled for the state examinations, they have a much better chance of teaching the materials in the manner in which they will be covered in the examinations. If this phenomenon occurs to any great degree, there must be a considerable loss of impact of the propagandizing materials. A further facet of this illustration is the fact that the evaluation of a teacher's success is based largely upon the success of his students in the examinations.

${ }^{18}$ Gunther, op. cit. p. 292.

${ }^{1}$ United States Department of Health, Education, and Welfare, Education in the USSR, op. cit. p. 87 . 
But there is no escaping the fact that the intent of the Communist party is to ideologically influence the mind of every school child through every possible avenue in the curriculum. Counts states:

The process of education in Communist morality is highly complex. It involves every teacher, every subject, every pupils' collective, every worker, and the entire regimen of the school. Everything must be organized and administered for the purpose of achieving the common goal.

The organization of instruction is particularly important. The way pupils study influences the development of conscious discipline and traits of will and character. Each subject has a special contribution to make in the shaping of attitudes, the acquisition of interests, and the forming of convictions. The roles of language, history, geography, and the sciences are fairly obvious. But even aesthetics has a contribution to make. "Understanding the beautiful," observes Kairov, "has an historical and a class character." 20

\section{The Youth Organizations}

The Communist party has taken particular pains to establish a system for developing loyal party members from among the ranks of the youth of the country. While still in nursery school, youngsters can become Little Octobrists. From about age nine to 14 , they may belong to the Young Pioneers. And from the more loyal of the Young Pioneers are selected the members of the Komsomol, or Young Communist League, which covers the age span of 14 to 26 years. There are about 20 million Young Pioneers, and about 18 million Komsomols.21 (The total Russian population is a little over 200 million.) The transition from the Komsomol to Communist party membership is accompanied by a further screening process, so that only the most eligible and best proved candidates may become party members.

The activities of the youth organizations cover the whole gamut of extracurricular and cultural activities. The Komsomols and the Young Pioneers are among the foremost agencies in the field of political education. They also provide a sounding board for party propaganda and a gauge by which the

\footnotetext{
${ }^{20}$ Counts, op. cit. p. 129-30.

${ }^{21}$ Gunther, op. cit. p. 228.
}

party can measure the effect of its measures on the younger generation.

The attraction and significance of these very active youth organizations cannot be overemphasized. Through their constant program of youth activities, their "houses" and "palaces," and their direct ties to the Communist party, they have served to enlist the youth of the country in nationalistic causes and have provided an organized outlet for propaganda.

The youth organizations must indeed be considered as arms of the educational apparatus of the Soviet Union. They are avowedly educational in character and in operation, and their influence on impressionable youth is undoubtedly salutary from the Communist point of view.

\section{Practical Matters}

In their effort to achieve the optimum educational investment in each youth, the Soviet leaders have had to cope with several practicalities. In some cases, they have experimentally tried patterns which have later proved to be unwise. These efforts have nonetheless had an influence on the youth in the schools.

In 1943, for example, it was decreed that coeducation should be abolished and that separate schools should be operated for boys and girls. In 1954 this policy was reversed. That its implementation was never really accomplished in the period 1943-54 is at. tested to by this observation made by a visitor to Moscow in 1954, when coeducation was still taboo:

It was startling to learn that in spite of the change in official policy, all but 2 per cent of schools and 12 per cent of pupils still have coeducation.22

Because of a serious shortage of school buildings, it has been necessary to operate schools on shifts, with sometimes as many as three shifts in a building. Several observers who have recently visited the Soviet Union have remarked, however, that there does not seem to be a shortage of teachers. ${ }^{23}$ This

22 "Visit to a Moscow School," (London) Times Educational Supplement; April 16, 1954. p. 337.

${ }^{23}$ Lawrence G. Derthick, "The Russian Race for Knowledge," School Life 40:3; June 1958. 
advantage undoubtedly can be attributed to the effectiveness of state planning in the direction of placing the required number of individuals into teacher education curricula.

Through the concentrated management of their resources, the Soviets have achieved a near-deification of education. Counts relates that the Soviet Union "has marshaled all the forces of organized education to achieve its purposes and advance toward its distant apocalyptic goals." He continues that it "has employed the full force of education to change the course of history and the nature of man."24 President Hatcher has metaphorically likened the educational system to a great power plant, which the Soviets have felt they must build first in order for other things to follow. ${ }^{25}$

A great deal of popular support is accorded education. Estimates are that something like 7 to 8 per cent of the national income goes into education (vs. about 3 per cent in the United States). Collective farms and industrial plants lend direct support to the schools and often co-operate with them on a direct and intimate basis. In rural areas the school is often the center of the cultural life of the district.26

Perhaps the strongest coercion of Soviet youth is the incentive system which is used to draw him onward. ${ }^{27}$ Great rewards lie in wait for those who diligently apply themselves to their studies. President Hatcher reported finding "the strongest incentive system I have seen anywhere." 28

The pressures for academic success bear strongly upon the pupil. While repeated efforts will be made to help the child through his studies (e.g., he may repeat any year's work in the ten-year curriculum if necessary), there is a definite stigma accruing to the pupil and to his teacher if this occurs. There are thus subtle penalties attached to academic failure.

\footnotetext{
${ }^{24}$ George S. Counts, "Soviet Education and Soviet Power," Educational Digest 23:2; September 1957 .

${ }^{25}$ Hatcher, op. cit.

2A Harry Milne, "The Challenge of Soviet Education," Educational Digest 23:2; March 1958.

27 Fainsod, loc, cit.

s Hatcher, op. cit.
}

The Soviet youth who excels in academic pursuits will find his financial road quite easy, since the state takes a large part of the responsibility for his academic expenses. According to U.S. Commissioner of Education Derthick, the state pays stipends to approximately 80 per cent of the $1,100,000$ full-time students in institutions of higher education. None of these students pays tuition. ${ }^{29}$ Draft deferments are also available to those students who keep their studies up. While they must take some military training along with their regular academic pursuits, the prospect of continued deferment from active military duty again operates as a distinct pressure of the student to remain in school and to do as well as possible in his work.

\section{Soviet Attitudes Toward Their Program}

Informed Americans cannot help but observe that the heavy emphasis on scientific and vocational pursuits in the Soviet Union has dealt a body blow to the humanities and the arts. The curriculum depicted in Table I would certainly convey this impression, as would many outside observations made by students of Soviet society. The matter of individual acceptance of the large degree of regimentation in the Soviet educational scheme has also raised questions in American minds.

These questions have been equally obvious to the many Americans who have recently visited the Soviet Union, and several of them have inquired of Soviet citizens just what their attitudes are toward the general education program.

For example, President Hatcher reported that he raised the question of the neglect of the humanities and the arts with several Russian people with whom he came in contact. The answer, as we might expect, was an unqualified denial of the charge. The Russians reported that they actually accomplished more in these areas in their ten-year schools than the United States does in 12 years. They pointed out that much of the child's education in the humanities and the arts comes from his immersion in the total Soviet culture, under the guidance of his

${ }^{29}$ Fred M. Hechinger, "U.S. Mission Finds Soviet Education Is Grand Passion," New York Times, September 6, 1959. p. 42. 
superiors. ${ }^{30}$ This extra-curricular activity includes an impressive program of visits to museums, libraries, concerts, and other cultural buildings and events. Visitors to the Soviet Union have reported seeing such student groups on tour frequently, and there is no reason to discount their educational value.

A statement by a leading Soviet educational official concerning cultural education resulted from an inquiry by the Times of London just after the launching of the Sputniks in the fall of 1957. The question was addressed to Mrs. Lyudmila Dubrovina, deputy minister of education of the Russian Republic, and her cabled answer is reproduced below. This rather extensive quotation is presented to show the influence of party thought and the general ambiguity of the statements:

Question: Has the Soviet Union's development of scientific studies led to any neglect of general cultural education?

Answer: The curricula of the Soviet schools are specially directed toward fostering general cultural education. In addition to mathematics, physics, chemistry, biology, the elements of production, and draughtsmanship, they provide for the study of those subjects which give the students a knowledge of the humanities, an aesthetic education, and a high standard of general cultural attainment. ..

Education in the spirit of socialism has brought about radical changes in the spiritual and moral make-up of the Soviet people. They are imbued with the spirit of love and devotion to their socialist homeland. At the same time all racial or national prejudices are alien to them. In the spirit of humanism they are brought up to be cheerful and buoyant, to perform exploits in labor and science, and not to rest on their laurels. Thus the development of scientific research in the Soviet Union has not led, and clearly could not lead, to any neglect of general cultural education. For both are interdependent integral parts of the cultural and technical revolution accomplished in our country. They are two interconnected aspects of the process of cultural-political and scientifictechnical growth towards carrying out mankind's age-old dream of building the perfect Communist society. ${ }^{31}$

\footnotetext{
${ }^{30}$ Hatcher, op. cit.

a1 "Pyramid to Outer Space-The Educational Foundations," (London) Times Educational Supplement, December 6, 1957. p. 1551 .
}

The acceptance of regimentation is something which Soviet youth have come to accept quite routinely. Soviet youth wonder, in fact, why American youth are not quite displeased over their lot in having to pound the pavement to look for jobs after graduation. The University graduate in the Soviet Union is automatically assigned his first job after graduation, and he is expected to work at it for three years. This he accepts in good grace as a necessary part of the system which largely subsidized his education. This arrangement and the students' attitude of it has been compared to our military academy graduates, who also must agree to serve in the armed forces for a certain period of time after graduation.

\section{Current Reform}

One has only to dip briefly into Soviet educational history to recognize that many gyrations have taken place in policy and practice. Ideological changes have been responsible for much of the flux. The study of Soviet education is complicated by these shifts in the party line, for the educational system is of prime concern to party leaders and political shifts often result in educational shifts. The currency of observations on the Soviet educational system must always be questioned, since changes sometimes occur quite dramatically.

The latest major changes in Soviet educational practice are contained in a new law enacted by the Supreme Soviet on December 24, 1958, entitled "Law on Strengthening the Ties of School with Life and on the Further Development of the System of Public Education in the USSR."32 Prior to the enactment of this legislation, there had been several indications of growing dissatisfaction with the Soviet educational plan. The criticism was first heard at the Twentieth Communist Party Congress in 1956. Read $^{33}$ and others confirmed the discontent observed during visits to the Soviet Union, and suggested some of the directions which reform might take.

The intent of the new law is to bring the schools "closer to life," and to require all

\footnotetext{
${ }^{32}$ Medlin, op. cit., p. 126.

${ }^{33}$ Gerald Read, "The Big Reform in Soviet Education," Phi Delta Kappan 40:194-99; February 1959 .
} 
pupils to engage in "socially useful labor" during their school days. To accomplish this, the law contains provisions which will lead to an increased emphasis on polytechnic education for all youth. The criticism which ultimately led to legislative action centered mainly around the feeling in the Communist Party that some youth were becoming soft, that they were avoiding hard work, and that they were interested only in career berths in the white-collar occupations. Hechinger has reported that a further consideration behind the law was "an attempt to stop the massive rush to the universities and to provide instead more skilled manpower for technology on a level that does not require university training." 34

The most significant provision of the new legislation is that concerned with extending the traditional seven-year school by one year, thereby establishing what is known in offcial terms as an eight-year "incomplete, general educational, labor, polytechnical school."35 The one-year extension was apparently felt necessary to compensate for the increased amounts of work experience henceforth to be expected of school-age youth. The intent is to make this basic eight-year educational program compulsory and universal throughout the Soviet Union, with all youths (except the really gifted) expected to engage in some form of productive labor after graduation. Some changes will also be made in the curriculum as the conversion to the eight-year program takes place.

While the proposed eight-year education will constitute terminal education for many students, and is indeed so intended, there will be three types of secondary schools in which the youth may continue their education on a part-time basis, through evening and correspondence instruction.

One observer reports that "once the reorganization is complete the ten-year schools will be converted to eleven-year schools and a third of their work will be devoted to more sophisticated shop work and practical experience. . . . It seems that all the existing ten-year schools will stay in operation in the new format."36 Presumably they will

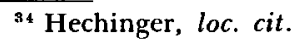

${ }^{35}$ Medlin, op. cit., p. 128.

${ }^{38}$ Max Frankel, "Changed Schools Reopen in Soviet," New York Times, September 2, 1959, p. 20. also continue to be the prime source of university matriculants.

Another type of special school should be mentioned. A system of secondary (elevenyear) boarding schools has been instituted which, it is predicted, will "continue to develop and expand until some two and a half million youth attend them in 1965."37 Korol states that the boarding schools are visualized as a model for future developments in Soviet education. ${ }^{38}$

The boarding schools are thus a reflection of the attitude of the state toward the importance of the training of the young. Specifically, the importance attached to this kind of training has been observed to indicate that the influence of the father and mother on a child is often improper, i.e., contrary to the best over-all interests of the state. Thus the complete dominance of the idea that the individual owes his first responsibility to the state becomes coldly apparent, to the point that the child-state relationship assumes more importance than the child-parent relationship. Lenin, in fact, said that children should become the sole charge of the state. ${ }^{39}$

There have also been recent evidences of a "Western" variety of juvenile delinquency in the Soviet Union and some observers feel that the new boarding schools are geared as much to stop delinquency as to train leaders. ${ }^{40}$

Certain reforms have also been legislated for higher education in the Soviet Union. As with the changes affecting the other schools, these specify increased attention to practical experience, and a greater emphasis on evening and correspondence education to enable students to spend more time than they have previously familiarizing themselves with the work-day world. Students with work experience records will generally be given preference in admission to the universities. Certain organizational changes in higher education will also be carried out.

\footnotetext{
${ }^{37}$ Read, op. cit., p. 197.

${ }^{38}$ Alexander G. Korol, Soviet Education for Science and Technology (Boston: John Wiley and Massachusetts Institute of Technology, 1957) p. 36.

${ }^{39}$ "Schools in Russia: Devouring the Mind," Newsweek 48:114; October 29, 1956.

10 Ibid.
} 
It is, of course, too early to make any valid observations on the real scope and effect of the changes destined to follow the school reform legislation. The first changes were begun only in September, 1959, and at that time Frankel reported in the New York Times, from Moscow, that the changes which he observed could be described as a "mod. erate switch of emphasis." 41 He reiterated that "it will be five years before (the changes) are fully worked out and placed into effect." Observers have differed somewhat in their estimation of the impact of the school reform program, and only time will reveal its true significance.

\section{The Future}

What long-range effect is the Soviet pattern of general education having on its youth? What is likely to happen in the foreseeable future as a result of the kind of education now being promulgated so avidly in the Soviet Union?

These are, of course, difficult but allimportant questions. Unquestionably, the inquiring mind which is fostered by a heavy emphasis on science and the scientific method will eventually insist on answers to questions which have, to this date, been omitted from the education of the Soviet youth. There are evidences already that the youth are eager to learn more about the outside world, and that they are interested in facts-not Communist-filtered propaganda. This attitude is not widespread yet, but President Hatcher reported the instance of a Soviet youth who discussed with him the possibility of obtaining greater numbers and more representative translations of English and American authors. 42

The more optimistic observers predict that in creating a super-educational machine the Soviets have indeed sown the seeds of their own downfall. Wendell Wilkie is quoted as having remarked to Stalin in 1942:

If you continue to educate the Russian people, Mr. Stalin, the first thing you know you'll educate yourself out of a job. ${ }^{43}$

${ }^{41}$ Frankel, loc. cit.

42 Hatcher, op. cit.

43 Allen W. Dulles, "Education in Russia May Defeat Communists," U.S. News and World Report 39:127; September 16, 1955.
Allen W. Dulles, head of the Central Intelligence Agency of the United States, has stated:

In introducing mass education, the troubled Soviet leaders have loosed forces dangerous to themselves. It will be very difficult for them henceforth to close off their own people from access to the realities of the outside world. ${ }^{44}$

There is a potential "boomerang" effect in the current Soviet emphasis on science and technology which can easily be overestimated, but is nonetheless real. DeWitt comments on this:

In the Soviet setting, the creatively inclined individual is most likely to seek escape, yes, indeed, escape, from political and social reality, from the theology of communism, in a scientific or engineering career. It is a paradox, a tragic dilemma of Soviet science education that it is propelled by psychological forces largely not of its own making. Many good men who flock to its ranks are there to escape the hazards of political reality, to seek a safer haven, and to preserve the tiny bits of human honesty and dignity largely destroyed or shattered in the hypocrisy of communist tyranny. ${ }^{45}$

Allen Dulles, in a commencement address delivered at Columbia University, said:

Possibly for a time the Soviets will go forward, using their educational system as a sorting device for human assets. Half-educated men-all fact and no humanity-may still be good fodder for totalitarianism. Possibly the Soviet leaders will encounter problems for which they will seek the solutions by foreign adventures. But there remains the possibility that newly created wants and expectations, stimulated by education and perhaps by more exposure to the West, will in time compel great and almost unpredictable changes in the Soviet system itself. ${ }^{*}$

During 1959 and the early part of 1960 (before the collapse of the Summit Conference in May, 1960) there was a noticeable lessening of tension behind the Russian facade. The Hatcher party was received most hospitably in April and May, 1959.

4Ibid., p. 128.

15 Nicholas DeWitt, "Soviet Science Education and Its Challenge," in Kermit Lansner (ed.), Second-Rate Brains (n. p.: Doubleday, 1958) p. 18.

${ }^{16}$ Dulles, op. cit. p. 128. 
Other reports indicate similar overtures of friendliness on the part of Russian leaders and particularly on the part of the Russian people.

These friendly gestures were generally interpreted to mean that the Russians had so much confidence in their system and in their doctrinaire hold on their youth that they could well afford the risk of letting them converse freely with representatives of the West. The amiability of the Soviets was thus undoubtedly an expression of the party line, which indicated that it was advantageous to begin a certain degree of intercourse with the West.

President Hatcher has interpreted this same phenomenon differently. He explains that the present generation is one which "knew not the Czar," that in fact this generation is one whose experience dates from a more recent level. Not having known first-hand the oppression which their forebears experienced, they are less inclined to recognize and/or appreciate the saving graces of the Communist-controlled state. One observer has said, "Give them another ten years and they will defeat Communism." 47

Thayer predicts:

By the time they have solved their own problems and are ready to conquer the world for communism, they may also discover that the little gremlins in the Kremlin haven't left them as much communism to spread around the globe as they imagine they have. ${ }^{48}$

It is significant to note that even when it is viewed apart from the machinations of the Communist party, the Soviet educational system is a highly efficient and successful enterprise. Allen Dulles ${ }^{49}$ and others have commented that defectors and emigres from the Soviet Union still retain a great deal of pride in the education which they received in Soviet hands.

\section{Conclusion}

Several factors stand out in the study of the education of Soviet youth:

1. General education as we know it in the United States is non-existent in the Soviet Union. The academic work which corre-

${ }^{47}$ Hatcher, op. cit.

4 Thayer, loc. cit.

19 Dulles, op. cit., p. 124. sponds closest to our concept of general education is completed in the elementary and secondary grades, grades 1 to 10 . At the universities and other institutions of higher education students are required to take almost all of their work in their field of specialization, as they are in almost all continental European universities.

2. Indoctrination in Communist ideology permeates all phases of Soviet education. The schools are regarded as a primary agency for instilling loyalty and dedication to the objectives of the Soviet state as decreed by the Communist party.

3. The individual counts for nothing in the Soviet Union, except as an instrument which can be molded to aid in the attainment of Communist objectives. Hence, the emphasis in education is not the enrichment of the individual for the individual's sake, but exclusively for the state's sake. This is quite different, of course, from the American concept of general education, which is primarily to aid the individual in self-realization and secondarily to help him make a signifcant contribution to the national economy.

4. There is a considerable rigidity extending throughout the entire Soviet educational system. Student choice is minimized as a result of the compelling demands of the planned economy. All students in grades 1 through 10 take the same subjects at the same time, over the entire country, with very few exceptions. Depending on aptitude and achievement, students are directed into fields of specialization where they can make the greatest contribution to the state. Once they have embarked on a goal which they are competent of attaining, they are not permitted to change careers as American students are.

5. There is a heavy emphasis on the nobility of manual labor and industrial production in the education of all youth. Students are taught not only to respect but to be eager to participate in various kinds of practical endeavors. The children are required to engage in various agricultural and industrial projects, not only as part of the curriculum, but after school or during school vacations. Appropriate recognition is given for such activity.

The recent school reform legislation, which places great stress on polytechnic 
work experience for all youth, will serve to increase national productivity and to discipline the student in the dignity of work and help him to sharpen his own vocational goals.

6. Women are accorded essentially the same educational and vocational opportunities as men in the Soviet Union. There seems to be complete acceptance of women in almost any profession, and their training is the same as that for men with only a few minor exceptions.

7. The party-sponsored youth organizations play a significant part in the education of Soviet youth. The Little Octobrists (to age nine), the Young Pioneers (age nine to 14), and the Komsomols (age 14 to 26) provide an opportunity for extracurricular activities of many kinds. The programs of these organizations are purposely designed to attract and retain the bright, aggressive youngsters who will some day become party leaders. These organizations thus provide a training ground for leaders, a sounding board for propaganda, and an intensive activity program of an educational nature.

8. There is a strong system of incentives at work in Soviet education. Numerous devices are employed to glorify academic attainments (silver and gold stars, "hero" titles, etc.), and all children are made to realize that the greatest prestige attaches to academic or research careers. Financial rewards come quite readily to those who do well in their studies. Draft deferments are also continued for the academically talented. One of the currently suggested reforms in Soviet education has to do with establishing special schools for gifted pupils in mathematics and science in addition to those now existing for the arts.

9. Visitors to the Soviet Union report that there seems to be a favorable acceptance of the Soviet educational system among the people, and that the leaders believe it to be almost above reproach. Defectors from the Soviet Union have, in spite of their break, held the educational system in high esteem. There is every indication that the Soviets have "paid for education and are making it pay."

10. It is not only desirable, but imperative, that Americans labor diligently to un- derstand the Soviet people, politics, geography, and educational system. The kind of mutual ignorance now extant in both the United States and the USSR relative to the culture of the opposite country is in itself a threat to world peace, and one which could be ameliorated through increased study of the many available publications. Our people should be encouraged in every way possible to learn more about the Soviet Union.

\section{Bibliography}

Benton, William. This Is the Challenge. New York: Associated College Presses, 1958. $254 \mathrm{p}$. "William Benton Reports on the Voice of the Kremlin," The 1956 Encyclopedia Brittanica Book of the Year. Chicago: P. F. Collier and Sons, 1956. Feature article; pages unnumbered. Counts, George S. The Challenge of Soviet Education. New York: McGraw-Hill Book Company, Inc., 1957. $330 \mathrm{p}$.

- - - "Soviet Education and Soviet Power," Educational Digest 23:1-4; September 1957.

Derthick, Lawrence G. "The Russian Race for Knowledge," School Life 40:3-4; June 1958.

DeWitt, Nicholas. "Soviet Science Education and Its Challenge," Second-Rate Brains. Kermit Lansner, ed. (n.p.): Doubleday and Company, 1958.

--_. Soviet Professional Manpower: It Education, Training, and Supply. Washing ton: National Science Foundation, U.S. Government Printing Office, 1955. $400 \mathrm{p}$.

DODge, Homer and Dodge, Norton. "Russia Gains Over U. S. in Educating Scientists," U.S. News and World Report 37:94-98, 100, 102, 104; September 16, 1955.

Dulles, Allen W. "Education in Russia May Defeat Communists," U. S. News and World Report 39:124, 126-28; September 16, 1955.

Fainsod, Merle. How Russia Is Ruled. Cambridge, Massachusetts: Harvard University Press, 1958.

Gunther, John. Inside Russia Today. London: Hamish Hamilton, 1958.

Hatcher. Harlan. "Our Soviet Neighbors." Speech delivered at the University of Michigan, Ann Arbor, May 21, 1959.

"How Russia Does It," (London) Times Educational Supplement, November 29, 1957.

Korol, AleXander G. Soviet Education for Science and Technology. New York: John Wiley and Sons, Inc., and the Massachusetts Institute of Technology, 1957.

KOROLEv, F. Education in the USSR. London: Soviet News Booklet No. 24. (n.d.) .

MiLne, Harry. "The Challenge of Soviet Education," Educational Digest 23:1-3; March 1958. 

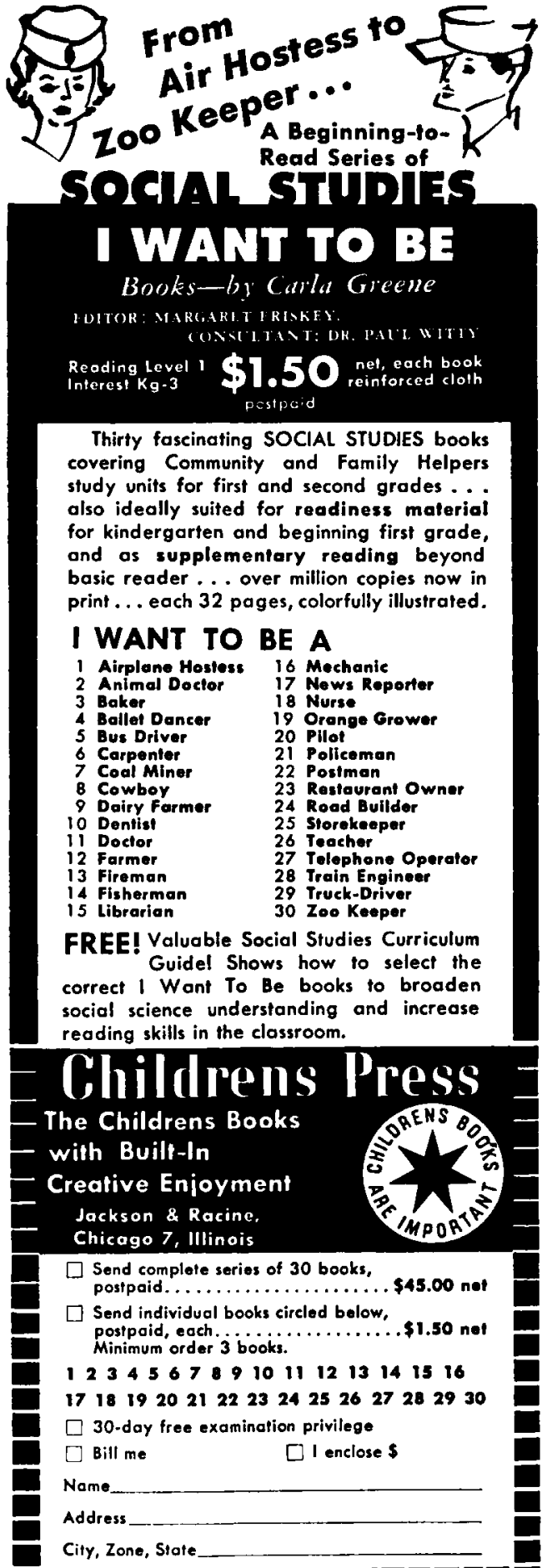

"The One-Track Mind," Time 66:46-49; November $28,1955$.

"Pyramid to Outer Space-The Educational Foundations," (London) Times Educational Supplement, December 6, 1957.

ReAd, Gerat.d. "The Big Reform in Soviet Education," Phi Delta Kappan 40:194-99; February, 1959.

"Schools in Russia: Devouring the Mind," Newsweek 48:110, 112, 114; October 29, 1956.

"Soviet Educational Structure," (London) Times Educational Supplement, November $20,1953$.

Thayer, Charles W. "I Found Russia Changed," Saturday Evening Post 228:155-58; April 14, 1956.

United States Department of Health, Education, and Welfare; OfFICE OF Education. Education in the USSR. Washington: Government Printing Office, 1958.

-_- Soviet Commitment to Education. Washington: Government Printing Office, 1959.

"Visit to a Moscow School," (London) Times Educational Supplement, April 16, 1954.

Widmayer, RUTH, "The Evolution of Soviet Educational Policy," Harvard Educational Review 24:159-75; Summer, 1954.

-- - - " "Recent Developments in Soviet Education," School Review 63:438-42; November 1955.

\section{BOOK MANUSCRIPTS INVITED}

If you are looking for a publisher, send for our free, illustrated booklet lifled To the Author in Search of a Publisher. It tells how we can publish, promote and distribute your book, os we have done for hundreds of other writers. All sublects considered. New authors welcomed. Scientific and scholarly works in limited editions a specialty. Write today for Booklet JT. It's free.

\section{VANTAGE PRESS, INC. 120 West 31 st Street New York 1}

In Washington, D.C.: 1010 Vermont Ave, N.W. In Calif.: 6253 Hollywood Blod, Hollywood 28 